\title{
MODELING THE VOLUME OF PRODUCTION IN SMALL AND MEDIUM ENTERPRISES IN THE REGIONS OF RUSSIA

\author{
Iuliia Pinkovetskaia ${ }^{1}$
}

\begin{abstract}
The object of the study is the consideration of all small and medium enterprises (SMEs) that are located in each of the regions of Russia. The purpose of the research is the evaluation of two-factor production functions that describe the dependence of the production volume of SMEs from the wage of employees and the fixed assets. The data for this reaseach was obtained from the official statistical observation of activities of all Russian SMEs in the 82 regions of Russia for 2015. The study allowed to determine the factors influencing turnover of SMEs located in all regions, to prove the high quality of approximation of the initial data by the two-factor production functions. The functions which were determined show that the economy of the regions of the country have not yet reached a saturation point with the goods and services of SMEs, and that they have increasing returns of scale in production in addition to considerable reserves for further development. Because sum of the degree values in the coefficients of the production functions is more than 1 and with the increase of both factors production growth is faster than the factors growth. The results of the study, namely new knowledge and tools for assessing production activities of small and medium enterprises in the regions, are of scientific and practical importance. They can be used by government and regional authorities to monitor the efficiency of investment in fixed assets and work resources, as well as the implementation of the Federal strategy for SMEs development for the period up to 2030. The methodology that were used in the research process can be applied to similar researches in countries with a significant amount of territorial (administrative) units.
\end{abstract}

JEL Classification Numbers: L26, C31; DOI: http://dx.doi.org/10.12955/cbup.v6.1187

Keywords: production function, enterprises, fixed assets, wage, regions of Russia

\section{Introduction}

In the emerging markets of Russia there are currently 5.6 million SMEs with approximately 18 million employees. SMEs are responsible for $20 \%$ of Russia's gross domestic product. The development strategy for the period up to 2030 (The strategy for the development of small and medium entrepreneurship, 2016) plans to increase the share of SMEs in the gross domestic product (GDP) twofold (up to 40\%). It envisages an increase of 35\% in the total number of employees in small and medium enterprises. SMEsare a major factor in regional development, especially in underdeveloped areas, and they create conditions for the structural adjustment of the economy (Acs et al., 2008; Baumol, 2004; Decker et al., 2014). Thus, currently in Russia there exists a significant need for the accelerated development of SMEs. Therefore, in recent years, one of the most pressing problems is the definition of reserves for the growth of SMEs in each region. The rationale for these reserves, as well as resources necessary for the effective functioning of SMEs, could be based on mathematical models such as production functions.

The number of employees of small enterprises should not exceed 100 people. Small enterprises include microenterprises which have no more than 15 people. The medium enterprises, on the other hand, range from 101 to 250 people.

The purpose of the research: the evaluation of two-factor production functions that describe the dependence of the production volume of SMEs on fixed assets and employee wages in each of the regions of Russia.

\section{Literature review}

Past literature has shown possibilities for the broad application of production functions in economic analyses and management. Production functions are economic-mathematical models of the processes of production Douglas (1967), Bessonov and Tsukhlo (2002), Kleiner (1986) and quantitatively expresses the steady, natural dependence between resources and production volume. Production functions are the basis for modeling the activities of a wide variety of production structures and systems, from individual enterprises and organizations to the regions, industries and economies of countries as a whole. In most cases, the resources are considered as capital input (the real value of all machinery, equipment and buildings) and labor input. The labor input in the various articles discussed different indicators. Hence in works by Bohórquez and Esteves (2008) and Husain and Islam (2016) the labor input discusses the number of permanent employees. And in the work by Sage and Rouse (2011) they consider the indicator of the total number of person-hours worked in a year. In the

\footnotetext{
${ }^{1}$ Ulyanovsk state university, pinkovetskaia@gmail.com
} 
majority of works, observations are based on temporary ranks. Hence the paper by Khatun and Afroze (2016) found the impact of the labor force and capital on the real GDP for some Asian countries namely, Bangladesh, India, China, Malaysia and Thailand using time series data from 1990-2014. The paper by Batool and Zulfiqar (2013) analyzes the input and output relationship of small and medium enterprises in Pakistan.

Researchers in Russia also have significant experience in the development of production functions. In the monograph "Factors of economic growth of the Russian economy" (2003) is discussed the theory of decomposition of growth on the factors of costs and the assessment of these factors. In the work by Kazakova (2013), it analyzes the properties of various production functions, discusses the problem of choice of their shape, and indicates the limitations associated with the use of different types of production functions. The work by Afanasiev and Ponomareva (2014) presented some results of the production function development in the Cobb-Douglas form to describe the process of expanded reproduction of the Russian national economy for the period of 1990 to 2003. The construction of the function on the Russian economy is also considered in the study by Antipov (2012), which specifies the appropriateness in the construction of the production function to use indicators in comparable prices and binding to one year. The work by Kirilyuk (2013) describes the results of a simulation, both for the economy as a whole and for its individual sectors. Principles of development of production functions across regions are reflected in the papers by Gafarova (2013), Baranov (2014), Adamaliev and Khalilov (2016). The first one presents the results of modeling of the gross regional product in the Republic of Bashkortostan. The second paper describes the features of the use of production functions in the regional studies, the wording of some simplifying assumptions and hypotheses. The third paper considers the equations of production functions expressing the dependence of the gross regional product of the cost of fixed assets, the number of employed in the economy. The analysis of literary sources showed that they mainly deal with production functions associated with the cost of labor as one of the factors. Typically, functions are developed on the basis of the time series. The literature analysis showed that the production function for the study of SMEs in Russia was used poorly.

\section{Methodology and design of production function SMEs and cross-sectional data}

All small and medium enterprises (SMEs) that are located in each of the Russian regions were considered as the objects of the study. Current law "On the development of small and medium entrepreneurship in the Russian Federation" (2007) established the basic criteria for classifying enterprises as micro, small or medium. That is, the number of employees for micro enterprises should not exceed 15 people, small businesses should not exceed 100 employees, and medium enterprises are above 101 employees, but should not exceed 250.

The production volume of goods, works and services produced by SMEs, is characterized by total revenue. It consists of the value of goods of SMEs production, performed by SMEs forces of works and services, as well as proceeds from the sale purchased on the side of goods.

In the production functions describing the activity sectors, regions and national economies the initial data is expressed often in monetary form (Modeling of economic processes, 2005). When determining the number of factors of production functions were taken into account the proposal of Granberg (1988). Granberg wrote about the feasibility of a small number of factors, that are convenient for the calculation and interpretation of results. The analysis showed that the greatest impact on the volume of production SMEs were factors such as fixed assets and the wages of employees. Salary is a complex indicator. It is more accurately compared with the number of employees, and describes the features of labor costs in a specific region (price level, employment and other socioeconomic aspects). In addition, the wages of employees can be used as a factor to give the same measurement (in rubles) of the production function. The same dimension of all indicators as shown by Felipe and McCombie (2012) ensures a high quality production function. Our study used cross-sectional data, which characterize the considered indicators for all SMEs located in each of the regions of Russia in 2015.

This approach was taken because the criteria for SMEs in recent years has repeatedly changed. The current criteria which is used are from 2008. This is because the accounting of SMEs is held once a year, and so simulations using time-series are possible only for a period of 8 years (2008 to 2015). Accordingly, the number of observations is eight, which is less than the minimum allowable value, because in order to be a two-factor function at least 16 observations are required Khodasevich (2017). Therefore, it is inappropriate for the evaluation functions to be constructed according to provisional 
data. As an example of using cross-sectional data it is possible to bring the paper Charoenrat and Harvie (2013).

In the process of research production functions were developed on SMEs data in all regions of Russia. The first function describes the activities of all SMEs located in each of the regions. Three functions correspond to the three groups of SMEs, which was formed on the above mentioned size categories: medium enterprises, small enterprises, and micro enterprises.

The study used official statistics. The study used data from the statistical observation of activities in all Russian SMEs in 2015 by Federal service of state statistics (2017). This observation is conducted every five years and gives more accurate information than the annual sample surveys of SMEs. The study is based on information from 82 regions of Russia.

The parameters of production functions were calculated using the methodology of regression analysis Pindyck and Rubinfeld (2013). During the development, we used methods of linearization and ordinary least squares.

\section{Production functions and evaluation of their quality}

The estimation of production functions that reflect the dependence of the production volume of SMEs on the value of fixed assets and wages of employees in the Russian regions is presented. Stated below are the formulas and tables developed by the author.

The first function describes the production volume of all SMEs located in each of the regions:

$$
y_{1}\left(x_{1}, x_{2}\right)=5.195 \times x_{1}^{0.561} \times x_{2}^{0.578}
$$

where $y_{1}$ - the production volume of all SMEs in the region of Russia for the year, billion rubles; $x_{1}$

- fixed assets of all SMEs in that region, billion rubles; $x_{2}$ - wage of employees of all SMEs in this region for the year, billion rubles.

The second function describes the production volume of medium enterprises:

$$
y_{2}\left(x_{3}, x_{4}\right)=6.595 \times x_{3}^{0.402} \times x_{4}^{0.721}
$$

where $y_{2}$ - the production volume of medium enterprises in the region of Russia for the year, billion rubles; $\boldsymbol{x}_{3}$ - fixed assets of all medium enterprises in that region, billion rubles; $x_{4}$ - wage of employees of all medium enterprises in this region for the year, billion rubles.

The third function describes the production volume of small enterprises (without micro enterprises):

$$
y_{3}\left(x_{5}, x_{6}\right)=6.849 \times x_{5}^{0.356} \times x_{6}^{0.779} \text {. }
$$

where $y_{3}$ - the production volume of all small enterprises in the region of Russia for the year, billion rubles; $x_{5}$ - fixed assets of all small enterprises in that region, billion rubles; $x_{6}$ - wage of employees of all small enterprises in this region for the year, billion rubles.

The fourth function describes the production volume of micro enterprises:

$$
y_{4}\left(x_{7}, x_{8}\right)=8.813 \times x_{7}^{0.535} \times x_{8}^{0.535} \text {. }
$$

where $y_{4}$ - the production volume of all micro enterprises in the region of Russia for the year, billion

rubles; $x_{7}$ - fixed assets of all micro enterprises in that region, billion rubles; $x_{8}$ - wage of employees of all micro enterprises in this region for the year, billion rubles.

The quality assessment of the obtained functions was performed using coefficients of correlation and determination, the Fisher-Snedecor test and the Student's t-test. 
The logical analysis of production functions showed that they adequately describe the patterns of activity of the respective sets of small and medium enterprises in the regions throughout the range of values of the factors.

Table 1 presents the estimated values of statistics for testing the quality of all the four production functions provided in the paper.

\begin{tabular}{|c|c|c|c|c|}
\hline Table 1: Values of the calculated statistics of functions \\
\hline Quality assessment & \multicolumn{4}{|c|}{ Calculated values of the functions } \\
\cline { 2 - 5 } & $(1)$ & $(2)$ & $(3)$ & $(4)$ \\
\hline Coefficient of determination & 0.952 & 0.915 & 0.952 & 0.961 \\
\hline Coefficient of correlation & 0.976 & 0.956 & 0.976 & 0.980 \\
\hline $\begin{array}{c}\text { Calculated value of the Fisher- } \\
\text { Snedecor test }\end{array}$ & 758.443 & 401.803 & 737.317 & 948.787 \\
\hline $\begin{array}{c}\text { Calculated value of the Student's t-test } \\
\text { on } \boldsymbol{y}\end{array}$ & 9.388 & 13.774 & 12.924 & 13.958 \\
\hline $\begin{array}{c}\text { Calculated value of the Student's t-test } \\
\text { for the first factor }\end{array}$ & 5.326 & 4.307 & 3.368 & 5.540 \\
\hline $\begin{array}{c}\text { Calculated value of the Student's t-test } \\
\text { for the second factor }\end{array}$ & 5.979 & 7.716 & 8.178 & 5.690 \\
\hline Source: Author & & & \\
\hline
\end{tabular}

A comparison of calculated values listed in Table 1, with the values of tests presented in the literature, show that the production functions (1)-(4) are of high quality. The correlation coefficients are close to one. The closer the coefficient of determination is to unity, the closer to a functional dependence between production volume and the factors. According to Draper and Smith (1998) the functions are successful when the coefficients of determination are more than 0.8. In our case they are higher than 0.915. The difference between the unit and the coefficient of determination describes the proportion of dispersion that is due to the influence of other factors, which are not included in the functions. That is, it can be concluded that the functions (1)-(4) explain more than $91 \%$ of variation in the dependent variables. Accordingly, the other factors (which not considered here) account for no more than 9\%. The calculated values of all statistics are much higher than table value of the Fisher-Snedecor test that is 3.98 at the significance level equal to 0.05 . All the calculated values of the Student's t-test are more than the table value, which at the significance level of 0.05 is 1.99 . Therefore, functions (1)-(4) are of high quality.

\section{Discussion of achieved results}

The obtained production functions indicate the presence of certain regularities, which are characteristics of the entrepreneurial sector in the economy of regions of Russia. The values of the degrees for both factors in functions are positive and hence it can be stated that they encourage the development of small and medium enterprises by ensuring the increase in the costs of wages and the growth of fixed assets. The production functions for the considered range of values of the factors do not reach their maximum. This is confirmed by the fact that the values of marginal returns for both factors for all functions are positive on the considered variation ranges of factor values. From this it can be concluded that the regional economy has not reached saturation by the products of the entrepreneurial sector, and it has significant reserves for further development. In all regions of Russia, there are significant reserves for the increase of production volumes of goods and services in SMEs.

The sum of the values of the indicators of the degrees in the factors in all production functions is greater than one, which indicates increasing returns of scale. A similar trend is noted in Asian countries (Khatun and Afroze, 2016). With the increase of both factors (fixed assets and wages), production volume growth is faster than the factors growth. For example, with a growth of both factors in function (1) by $10 \%$, production volume increases by $11.39 \%$. The accelerated increase in production volume and at the same time the factors growth has important economic and social value. For the rapid increase in the production volume of SMEs in Russian regions it is expedient to provide simultaneous growth of both these factors. This will provide increasing returns to scale. It should be noted that for regions with excess working population (for example, the republics of the North Caucasus), the main direction for development of entrepreneurship is associated with an increase in 
employment and the creation of family businesses. In regions where there are not enough potential employees (Siberia and the Far East) the main direction for increasing the volume of production in SMEs is associated with the increasing of fixed assets. The cross derivatives of the production functions for each of the two factors are positive for all values of the range of factors changing, so increasing one of the factors improves the conditions for the use of another factor. Therefore, the growth of employees' wages improves the return on fixed assets. Conversely, the increase in fixed assets increases the level of utilization of the wages.

The second derivatives of all the isoquants are positive. The level of convexity decreases with the growth of SMEs, which indicates an increase in the elasticity of replacement factors: with the growth of production volume in entrepreneurial structures increasing the possibility of substituting one factor for another.

The factor of the wage of employees in the production functions effect the production volume of small enterprises and medium enterprises to a greater extent than the factor of fixed assets. For micro enterprises the influence of factors is the same. Practical significance of the research lies in the possibility to use the results for the justification of resources and monitoring the level of entrepreneurship development. Functions (1)-(4) are not overloaded by secondary factors.

\section{Conclusion and proposals}

The study is unique and possesses novelty for estimating the production functions of SMEs in Russia. In addition, the novelty associated with the using spatial data on Russian SMEs. And also as a factor of labor was used such indicator as cost wage SMEs employees. The paper presents the results of a simulation of dependency production volume of small and medium enterprises from fixed assets and employee wages and discusses the results of the evaluation of two-factor production functions. The simulation was carried out on the basis of official cross-section statistical data for 2015 for SMEs located in all regions. The modeled functions were for all SMEs, and for three dimensional categories. A high quality approximation of the original data using production functions was proven.

The determined functions showed that the economy of the Russian regions has not reached a saturation point by the goods and services of SMEs. It addition, it was shown that the economy has increasing returns of scale in the producing and considerable reserves for further development.

The research results can be used by government and regional authorities to monitor the efficiency of investment in fixed assets and work resources. That is, to assess the level of efficiency of each of the discussing factors, as well as identify imbalances in the values of the factors for each of the regions. The functions can be used in the justification of fixed assets and labor resources, and in the formation of plans and programs for the further development of SMEs. The results of the study must ensure the implementation of the Federal strategy of SMEs development for the period up to 2030 (The strategy for the development of small and medium entrepreneurship, 2016).

Further research can be conducted on the analysis of the level of using fixed assets and wages of employees in the Russian regions and individual municipalities.

\section{References}

Acs, Z., Desai, S., \& Hessels, J. (2008). Entrepreneurship, economic development and institutions, Small Business Economics, 31, 219-234.

Adamaliev, K.R., \& Khalilov, M.A. (2016). Modeli proizvodstvennykh funktsiy regionov: raschet parametrov i kharakteristik, analiz zavisimosti vypuska produktsii ot zatrat resursov [Models of production functions of the regions: calculation of parameters and characteristics, analysis of the dependence of the output from the overhead]. Fundamental research, 4-2, 339-345.

Afanasiev, A.A., \& Ponomareva, O.S. (2014). Proizvodstvennaya funktsiya narodnogo khozyaystva Rossii v 1990-2012 gg. [Production function of national economy of Russia in 1990-2012], Economics and mathematical methods, 50(4), 21-33.

Antipov, V.I. (2012). Proizvodstvennaya funktsiya Rossiyskoy ekonomiki [Production function of the Russian economy]. Economics, Statistics and Informatics, 5, 101-104.

Baranov, S.V. (2014). Ekonomicheskiye modeli proizvodstvennykh funktsiy: istoriya i sovremennost' [Economic models of production functions: history and modernity]. Economic science, 10, 53-57.

Batool, S., \& Zulfiqar, S. (2013). Analyzing the Input Output Relationship of Small and Medium Enterprises in Pakistan: An Econometric Approach, International Journal of Business and Economic Development, 1(1), 66-73.

Baumol, W.J. (2004). Entrepreneurial enterprises, large established firms and other components of the free-market growth machine, Small Business Economics. 23. 9-21. 
Bessonov, V.A., \& Tsukhlo, S.V. (2002). Problemy postroyeniya proizvodstvennykh funktsiy v rossiyskoy perekhodnoy ekonomike [Problems of construction production functions in the Russian transition economy]. Analysis of dynamic the Russian transition economy. Moscow: Institute of economy transition period, 5-89.

Bohórquez, V., \& Esteves, J. (2008). Analyzing SMEs size as a moderator of ERP impact in SMEs productivity, Communications of the IIMA, 8(3).

Charoenrat, T., \& Harvie, C. (2013). Technical Efficiency of Thai Manufacturing SMEs: A Stochastic Frontier Analysis. Australasian Accounting. Business and Finance Journal, 7(1), 97-122.

Decker, R., Haltiwanger, J., Jarmin, R., \& Miranda, J. (2014). The Role of Entrepreneurship in US Job Creation and Economic Dynamism, Journal of Economic Perspectives. 28. 3. 3-24.

Draper, N., \& Smith, H. (1998). Applied regression analysis. New York: John Wiley \& Sons.

Douglas, P.H. (1967) Comments on the Cobb-Douglas Production Function. The Theory and Empirical Analysis of Production. ed. Brown M., New York: NBER, 15-22.

Factors of economic growth of Russian economy (2003). Moscow: IEPP.

Federal service of state statistics. (2017) Sploshnoye nablyudeniye za deyatel'nost'yu malogo i srednego biznesa za 2015 god [Continuous monitoring of the activities of small and medium businesses in 2015]. Retrieved November 12, 2017, from http://www.gks.ru/free_doc/new_site/business/prom/splosh.html

Felipe, J., \& McCombie, J. (2012). Problems with Regional Production Functions and Estimates of Agglomeration Economies: A Caveat Emptor for Regional Scientists. Cambridge Centre for Economic and Public Policy, Working Paper no. 725 .

Gafarova, E.A. (2013). Modelirovaniye regional'nogo razvitiya na osnove proizvodstvennykh funktsiy [The simulation of regional development on the basis of production functions]. Naukovedenie, 3, 1-7.

Granberg, A.G. (1988). Modelirovaniye sotsialisticheskoy ekonomiki [Modeling of the socialist economy]. Moscow: Economics.

Husain, S., \& Islam, M.S. (2016). A Test for the Cobb Douglas Production Function in Manufacturing Sector: The Case of Bangladesh. International Journal of Business and Economics Research, 5(5), 149-154.

Kazakova, M.V. (2013). Analiz svoystv proizvodstvennykh funktsiy, ispol'zuyemykh pri dekompozitsii ekonomicheskogo rosta [Analysis of properties of production functions used in the decomposition of economic growth], Moscow, RANHeGS, 2013, 48 p.

Khatun, T., \& Afroze, S. (2016). Relationship between real GDP and Labour and Capital by applying the Cobb-Douglas production function: a comparative analysis among, Selected Asian Countries Journal of Business Studies, XXXVII, 1, 113129.

Khodasevich, G.B. (2017). Obrabotka eksperimental'nykh dannykh na EVM. Chast' 2. Obrabotka odnomernykh massivov [Working with experimental data processing on computer. Part 2. Processing one-dimensional arrays]. Retrieved December 16, 2017, from http://dvo.sut.ru/libr/opds/i130hod2/index.htm

Kirilyuk, I.L. (2013). Modeli proizvodstvennykh funktsiy dlya rossiyskoy ekonomiki [Model the production functions for the Russian economy]. Computer research and modeling, 5(2), 293-312.

Kleiner, G.B. (1986). Proizvodstvennyye funktsii: Teoriya, metody, primeneniye. [Production functions: theory, methods and applications]. Moscow, Finance and statistic.

Modelirovaniye ekonomicheskikh protsessov [Modeling of economic processes], ed. by M.V. Gracheva, L.N. Fadeeva, \& Yu.N. Cheremnykh. Moscow: YUNITI-DANA.

On the development of small and medium entrepreneurship in the Russian Federation. Federal law, July 24, 2007, no. 209 FZ.

Pindyck, R., Rubinfeld, D. (2013). Microeconomics. New York: Pearson.

Sage, A.P., \& Rouse, W.B. (2011). Economic systems analysis and assessment cost, value, and competition in information and knowledge intensive systems, organizations, and enterprises. New York: John Wiley \& Sons.

The strategy of development of small and average business in the Russian Federation until 2030 (2016). Order of the Government of June 2, 2016. no. 1083-r/Russian Federation Code, 2016, No. 24, Art. 3549. 